\title{
PROTOTYPE DEVELOPMENT FOR THE EXTRACTION OF CRABMEAT
}

\section{CASSIO AURELIO SUSKI \& JENNY SUMARA SOZO}

Department of Education, Research and Extension / IFSC / Santa Catarina, Brazil

\begin{abstract}
In general, all the crab processed in Brazil is produced clandestinely and there are few national companies, legal and with SIF (Federal Inspection Services), producing the species at the present time. The few brands that display the product on the national market, label holders approved by the Ministry of Agriculture, inadvertently buy the raw material already processed by clandestine informal beneficiaries and only pack it. In the last decades, some equipment for the processing of crabs has been patented, but none is intended for the extraction of the dried meat of the crabs, that is, all have as their end result the crab pate (wet meat). The developed prototype provided a more efficient alternative in the extraction of crab meat in relation to traditional techniques of purely manual extraction and Mechanically Separated Meat (MSM). The developed prototype results in two distinct products, the crab pate and the dried meat. The extraction of the dried meat, by means of the principle of the generation of vacuum and without crushing it, that is to say, maintaining the natural fibers, added a greater value to the product, reduced the cost of the process and made possible the export.

KEYWORDS: Crab Meat, Callinectessapidus, Extraction Machine \& New Product
\end{abstract}

Received: Nov 15, 2017; Accepted: Dec 03, 2017; Published: Dec 20, 2017; Paper Id.: IJASRFEB20183

\section{INTRODUCTION}

The current competitiveness of companies is changing production processes and the globalized economy shows that the development of new products and processes brings advantages and extends the possibilities for the longevity and solidity of companies. In this scenario, the incorporation of innovation in products and technologies is fundamental so that companies can meet the increasingly demanding consumer, improve the working conditions of its employees and ensure the continuity and prospection of new markets.

In the fish segment, the development of Brazil's industry is still far below its potential and has a long way to go through in order to get closer to the world consumption average, which represents $1 / 4$ of animal protein (Josupeitet al, 2004). Brazilians consume on average $9 \mathrm{~kg}$ of fish per year, while the World Health Organization (WHO) recommends a consumption of $12 \mathrm{~kg} /$ citizen / year. This poor performance is mainly due to the poor quality of products and the lack of knowledge of the benefits of consumption. However, as the cultural development of the population occurs, the search for healthier foods increases, raising the demand for fish (Sidonio et al, 2012).

One of the fishery resources of great commercial interest is the Blue Crab (Callinectessapidus) a crustacean which comprises a variety of species exploited by man, mainly gastronomically, in the production of dishes like crab casks, stews and others. In relation to nutritional properties, the crab is a great alternative for health, because the fish has a great availability of essential amino acids, especially lysine, niacin and vitamins A, D1, B1 and B2 (Santos, 2006). In addition, the carapace is an important source of chitin and chitosan, compounds used in the pharmaceutical and cosmetic industry for production of supplements, skin reconstitution and biofilms 
for water treatment (Borgognoni et al, 2006; Moura et al, 2006).

In Brazil, the species Callinectessapidus is widely found as a companion fauna of several fisheries, especially shrimps, and / or captured by fishermen communities of low-income (Branco et al, 2004). C. sapidus is one of the most abundant and well-known species in the south and southeast regions of the country (Weber et al, 2000, and Pereira et al., 2009). Although much appreciated, there is a problem related to the adulteration of the product, many streak plasters knowing as Atlantorajacyclophora, which are captured for export purposes, are consumed domestically as crab meat, so that in many cases, the product sold as crab meat actually comes from another species of fish (Della Fina et al., 2015).

Most of the crabs marketed in Brazil are artisan ally benefited by riverine fishermen, who often have in this animal their main source of income / subsistence. One of the drawbacks of this processing is the lack of hygiene controls that pose risks to consumers for the possibility of contamination. In general, manual processing is unhealthy, burdensome and rudimentary and does not meet the standards of the regulatory sanitary bodies; they generally operate in precarious facilities and conditions.

In manual work the crustaceans undergo a quick cooking, have their entrails removed and then break and remove their carapace, so that it is possible to extract the flesh from the thoracic sternum, joints and locomotor members and, later, proceed to packaging stage for commercialization. During this process, there are several irregularities in Good Manufacturing Practice (GMP), which expose the final product to contamination risks.

The most recent technique of extracting crab meat is the mechanically separated Meat machines (MSM), where the body of the crab passes between two rollers and the product is a paste of a mixture of white and dark meat of crab, where the meats of the thoracic sternum and the pereiopods are laminated together.

In this process, the crabs are steamed in order to avoid contact with water and then sent to a processing line, where there is the withdrawal of the carapace, extraction of the viscera and finally passage through the pulp that performs the pressing of the crustacean, resulting in a paste. The final product has a low commercial value, because the market, mainly foreign, demand meats of more fibrous consistency.

In order to make the fish productive sector more active within the industry, it is essential to solve issues related to handling, processing, marketing and distribution. It is necessary to modernize the processing steps to improve the availability and popularization of the fish and offer a final product of better appearance, safety and quality. Considering that the projects of new products comprise the interaction between company and market, the innovations must be able to meet the expectations required for a given function, and systematize its construction.

The technique proposed by this study has sought the development of a machine of extracting the meat from the crab, avoiding direct human contact (manual dipping) and without the body being laminate (MSM machine), aiming the resulting product less exposed to the possibility of contamination in the processing, and, consequently, presents better conditions of sanity and quality, offering greater security to the consumers. At this juncture, the present work studied the methods to removal the meat and had as main objective to develop a machine for extraction of the dry meat of crab, aiming value aggregation, expansion of companies' portfolio, increase the commercial competitiveness and attendance the demand for quality derivatives of fish. 


\section{METHODOLOGY}

The methodology adopted in the machine for extraction of crab meat construction was proposed by Pahl et al (1996), and the project was developed from the following methodological guidelines: Planning phase, design stage, preliminary design and detailed design.

\section{Planning}

It begins by identifying the need for a new product and covers the detailed analysis of the design problem by raising all the information necessary for its full understanding. Scope and basic guidelines are defined to obtain the specifications, functionality and expected performance. The objective is to develop a set of information to provide the basis for extracting whole-grain crab meat and directing subsequent decisions.

In order to understand the existing manual removal and MSM processes, field trips to the city of Laguna-SC were carried out in fishing communities and a Processing Industry.

\section{Conception}

It is the stage of the process that generates a design for the product in order to meet the identified need efficiently. The possibilities for achieving the objective and specifications are investigated and then a functional product modeling plan is carried out.

In order to achieve the purpose, the conceptual design is divided into stages, which cover the identification of the initial problems of crab meat extraction, establishment of structures and functions, research of principles and solutions and culminate in the realization of design variants.

\section{Preliminary Project}

The best concept is chosen from the conceptions generated by the previous activities, which will be transformed into final product. For decision making to be successful, it is necessary to use selection methods. One of the most commonly used selection methods is the decision matrix method that uses evaluation criteria, which may be customer specifications or requirements. Solutions are presented to meet the functionalities required, so that, through the structural confection of the machine, a preliminary design is conceived. With the preparation of the prototype it is possible to check the errors and make adjustments to meet the specifications of the product.

\section{Detailed Project}

At this stage all components must be fixed, the shape, dimensions and layout of all structures must be definitively established and all materials and technical feasibility specified. According to Pahl et al (1996), the level of detail to be reached at this stage should include: Establishment of the definitive layout (general arrangement and spatial compatibility); Preliminary design of forms (component and material format); Production procedures and Establishment of solutions for any auxiliary function.

\section{RESULTS AND DISCUSSIONS}

The manual removal activity, whose substitution for mechanical activity is the scope of this work, has been studied in detail with the colony of fishermen who for generations have practiced informally this manual work of removal crab meat in the city of Laguna. 
It has been observed that traditionally it is an exclusively manual processing, unhealthy and costly. This rudimentary process is used by the crab collectors, who do not meet the standards of the regulatory bodies; they generally operate in precarious facilities and conditions.

The crab undergoes rapid cooking and has its locomotive limbs removed (Figure 1), after the carapace is removed (Figure 2), and then with the aid of a knife, the meat is extracted from the joints and locomotive members. Finally, a longitudinal cut is made in the thoracic sternum in order to expose the existing musculature and remove it (Figure 3). Once the removal procedure is finished, the product is packed in transparent plastic material (Figure 4) and goes on for commercialization.

In this processing, no GMP (Good Manufacturing Practices) regulations are followed, which compromises the food safety of the products and may endanger the consumer's health. Some of the factors that may pose a risk of contamination are the quality of the water used, the absence of gloves in the handling, equipment that does not go through adequate hygiene and sterilization processes, storage without temperature control, etc. In addition, in the carapace removal step, cuts and injuries are quite common due to the use of the knives in the carapace removal stage.

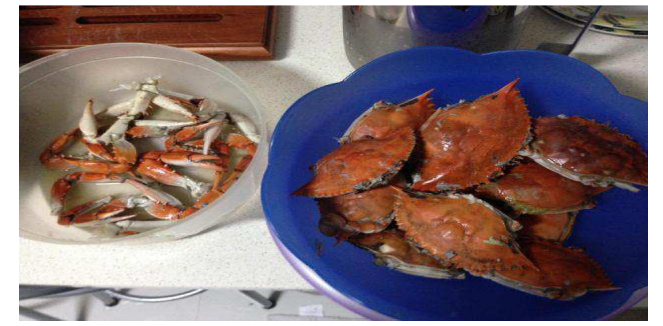

Figure 1: Cooked Crab without Locomotive Limbs

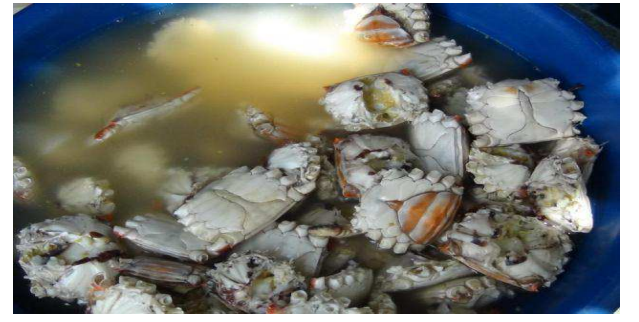

Figure 2: Removal of the Carapace
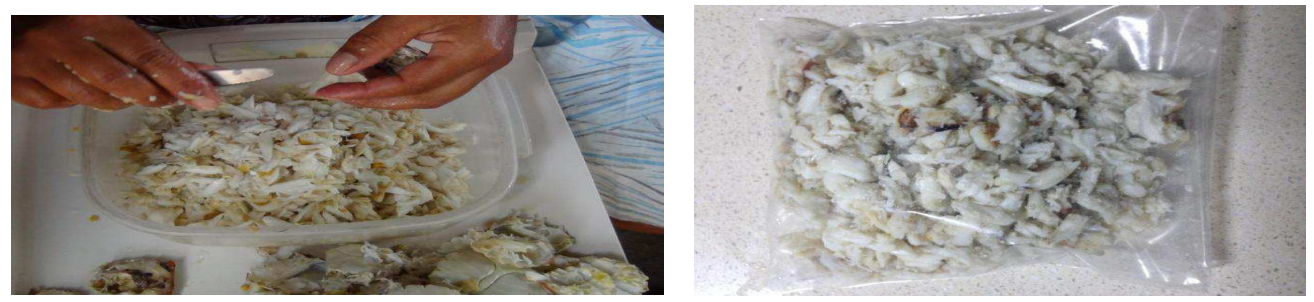

Figure 3: Manual Withdrawal of Crab Meat

Figure 4: Crab Meat Ready for Commercialization

In addition, through a technical visit to a processing company and a vast bibliographical review, a study was made on the operation of mechanically separated meat (MSM).

In MSM machines the body of the crab is pressed between two rolling cylinders and the product is a paste of a mixture of white and dark crab meat, the meats of the thoracic sternum and the pereiopods are pressed together. In this process, the crabs are steamed in order to avoid contact with water (Figure 5) and then sent to a processing line (Figure 6), where the carapace is removed (Figure 7), and entrails (Figure 8), finally passing through the crusher pressing, resulting in a paste (Figure 9), which is packaged and then can be marketed (Figure 10). The final product has a low commercial value, because the market, mainly foreign, demand meats of more fibrous consistency. 


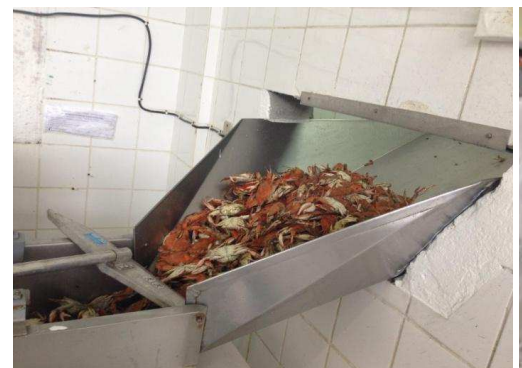

Figure 5: Steamed Crab

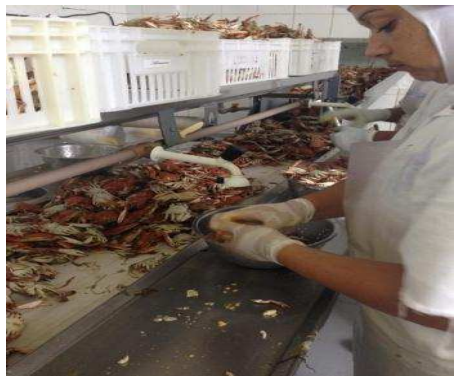

Figure 8: Extraction of viscer

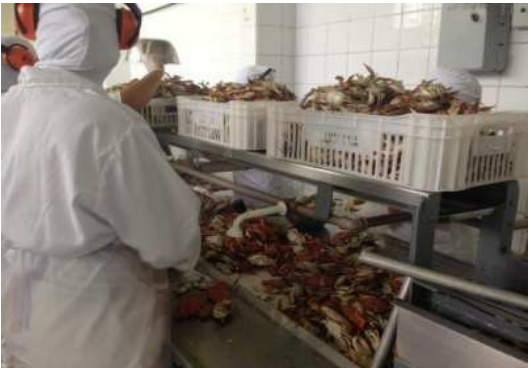

Figure 6: Crab Evisceration Processing Line

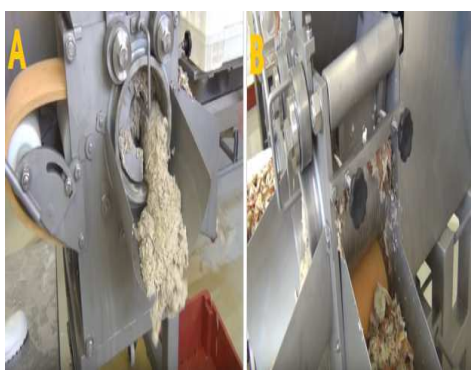

Figure 9: Crab processing

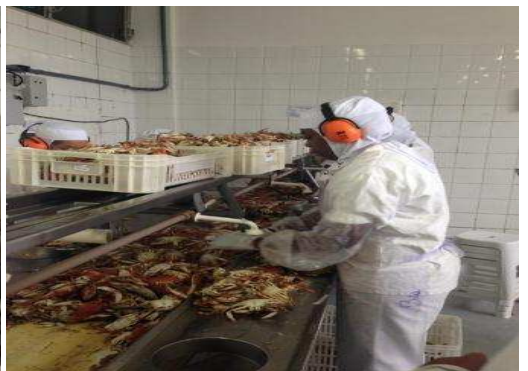

Figure 7: Removal of the Crab Carapace

by MSM

Thus, it has been found that the MSM process results in a crab paste with marked presence of water. This product does not meet the demands of the market for a product of superior quality and with better consistency characteristics.

From these observations began the development of suction meat extraction equipment. The first step was the planning stage, where the task was defined using the brainstorming technique, where by some questions were formulated and answered to better understand of the opportunity, justify it and bring some important characterizations, as shown in the table 1.

Through the gathering of the information, the needs that the machine was supposed to supply were determined, among which are: to remove the crab meat with a dry and fibrous appearance, need for refrigeration, to have facilities for use, assembly and disassembly, operation and repair, ensure safety and have an extended service life.

In addition, a technical feasibility analysis was elaborated, clarifying questions related to the production of the equipment, the suppliers, and the region of use, the technical profile of the team, the production process and the customers.

Once the task specifications had been elucidated, it was possible to proceed to the next machine design stage and, in order to determine the possibilities to meet the objectives outlined in the previous step, a physical-mechanical materials study were carried out. Through brainstorming and checklist it was possible to list the required functions and then identify the best resources to meet them, as can be seen in Table 2, where the selected alternative to the functionalities is highlighted. 
Table 1: Definition of the Task of the Crab Meat Extraction Equipment

\begin{tabular}{|l|l|l|}
\hline \multicolumn{1}{|c|}{ Item } & \multicolumn{1}{|c|}{ Questioning } & \multicolumn{1}{c|}{ Conclusion } \\
\hline Opportunity & $\begin{array}{l}\text { What is it about? What } \\
\text { does it consist of? How } \\
\text { useful? }\end{array}$ & $\begin{array}{l}\text { Crab Meat Extraction Method that meets hygienic sanitary requirements } \\
\text { for safe handling of food. It consists of equipment capable of enabling } \\
\text { the automation of the process improving the quality of the product as } \\
\text { well as the ergonomic working conditions of the operator. }\end{array}$ \\
\hline Justification & $\begin{array}{l}\text { Are there similar } \\
\text { machines? Is it a new } \\
\text { concept? Is it a Market } \\
\text { Need? }\end{array}$ & $\begin{array}{l}\text { Other machines with the principle have already been patented inside } \\
\text { and outside the country, but none with the specifications of removal of } \\
\text { meat with fibrous consistency. Therefore, it is a new concept that is } \\
\text { fully justified considering the current methodologies used for the } \\
\text { extraction of crab meat. }\end{array}$ \\
\hline Use & $\begin{array}{l}\text { What is the frequency of } \\
\text { use? Where is it used? }\end{array}$ & $\begin{array}{l}\text { The equipment will be used within the industry, in the companies of } \\
\text { beneficiation of crab, and in the communities of collectors or } \\
\text { associations, having a daily frequency of use. }\end{array}$ \\
\hline Description & $\begin{array}{l}\text { Is there a standard to } \\
\text { follow? What are the } \\
\text { requirements? What } \\
\text { materials can be used? }\end{array}$ & $\begin{array}{l}\text { Surveillance recommends standards for food handling; materials should } \\
\text { be easily sanitized and cannot be toxic. }\end{array}$ \\
\hline
\end{tabular}

The most suitable alternative for the operation of the equipment is alternating electric current, since it offers greater availability of energy and through the power it is possible to do the dimensioning of the thickness of the cables.

The various control devices and valves have been chosen to provide safety, ease of use and process efficiency. The selection of materials for the pipe, most suitable for each function, depends on several factors, such as the working temperature and the type of fluid to be conducted, where important aspects such as contamination and corrosion should be considered, as well as safety and flow resistance. After a study of the levels of tensile strength, expansion and thermal resistance, ductility and hardness, the non-toxic hose was the best option to suction the product, separate it and guide it to the reservoir, since it is light, high corrosion resistance, lower cost than other options, reduced coefficient of friction, low thermal and electrical conductivity, is translucent and allows visualization of the product and is also easy to manufacture and handle.

Table 2: Analysis of Structures and Functions

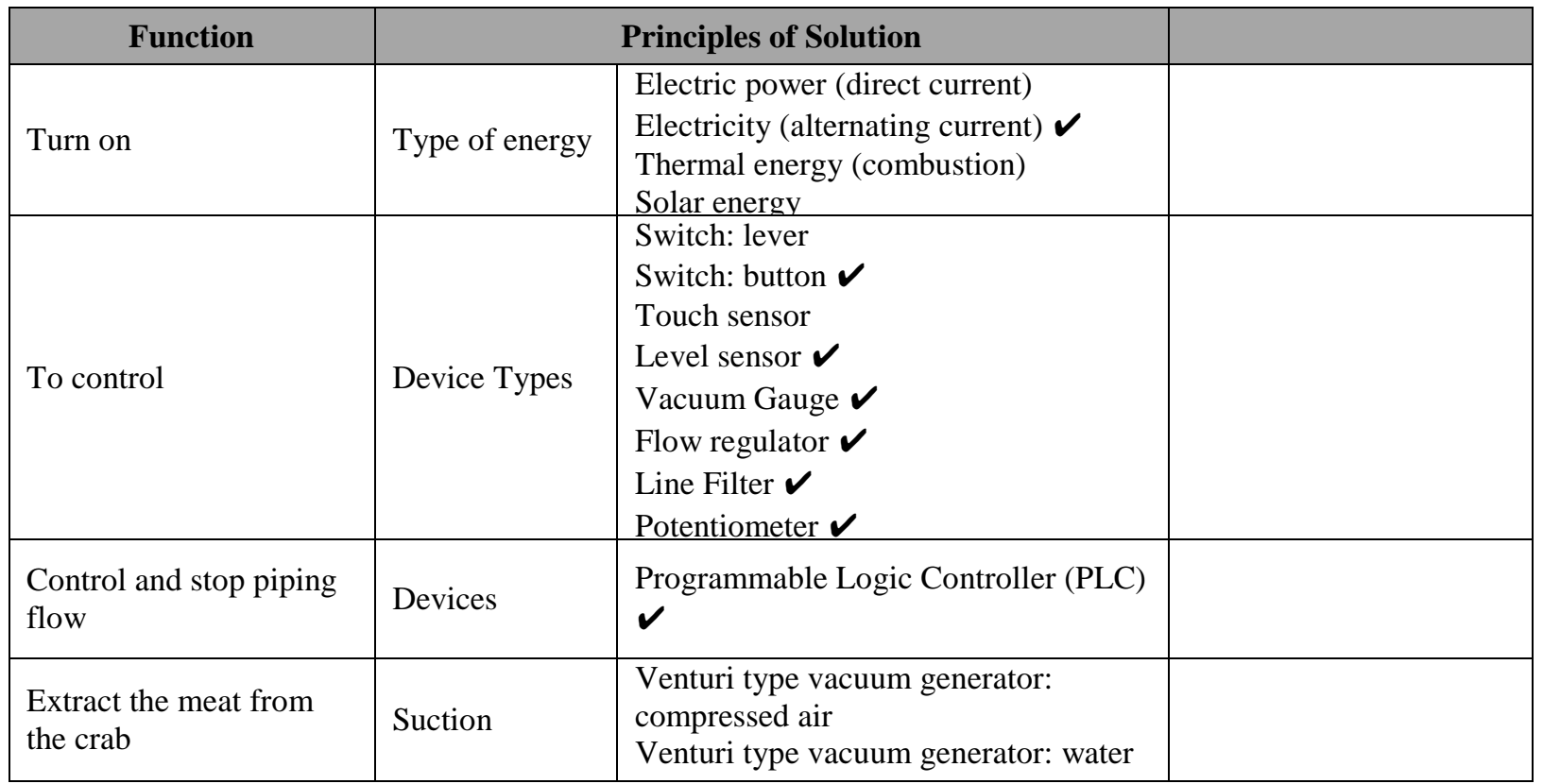




\begin{tabular}{|c|c|c|c|}
\hline \multicolumn{4}{|c|}{ Table 2: Contd., } \\
\hline $\begin{array}{l}\text { Guide the meat to a } \\
\text { suitable tank }\end{array}$ & $\begin{array}{l}\text { Pipes of } \\
\text { various } \\
\text { diameters }\end{array}$ & $\begin{array}{l}\text { Carbon steels } \\
\text { Cast iron } \\
\text { Alloy steels } \\
\text { Wrought Iron } \\
\text { Stainless steel } \\
\text { Aluminum } \\
\text { Brass } \\
\text { Nickel and alloys }\end{array}$ & $\begin{array}{l}\text { Polyvinyl chloride } \\
\text { (PVC) } \\
\text { Acrylics } \\
\text { Epoxy } \\
\text { Polyesters } \\
\text { Non-toxic hose } \boldsymbol{} \\
\text { Phenolic } \\
\text { Cellulose acetate }\end{array}$ \\
\hline Separate products & $\begin{array}{l}\text { Connections } \\
\text { with variations } \\
\text { in dimensions }\end{array}$ & $\begin{array}{l}\text { Polyvinyl chloride (PVC) } \\
\text { Stainless steel } \boldsymbol{V} \\
\text { Non-toxic hose }\end{array}$ & \\
\hline Connect the pipes & $\begin{array}{l}\text { Means of } \\
\text { connection of } \\
\text { pipes }\end{array}$ & $\begin{array}{l}\text { Threaded connections } \\
\text { Welded connections } \\
\text { Flanged connections } \\
\text { Tip and bag connections } \\
\text { Compression connections } \\
\text { O-ring }\end{array}$ & \\
\hline Store the meat & Reservoirs & $\begin{array}{l}\text { Material: } \\
\text { Stainless steel } \boldsymbol{V} \\
\text { Plastic Materials } \\
\text { Glass } \\
\text { Porcelain }\end{array}$ & $\begin{array}{l}\text { Kind: } \\
\text { Not refrigerated } \\
\text { Refrigerated } \boldsymbol{\checkmark} \\
\text { Thermal }\end{array}$ \\
\hline System feedback & $\begin{array}{l}\text { Reservoir } \\
\text { capacity }\end{array}$ & $\begin{array}{l}\text { Visual } \\
\text { Automatic } \boldsymbol{v}\end{array}$ & \\
\hline
\end{tabular}

\section{$\checkmark$ : Selected Alternative to the Required Function}

We opted for a refrigerated reservoir and of easy sanitization, to offer greater sanitary security, since the fish is a highly perishable food.

After concluding the conceptual study, we selected the best designs and proceeded to the stage of execution of the preliminary project where several prototypes were made with different configurations and dimensions, where we tested types of pipes, pumps and other components. In the initial tests it was not possible to obtain the dry meat / muscle fibers, because the resulting product had high water contents, so from these results were made improvements and adjustments and reached a structure that met the requirements required to ensure the extraction of the muscle fibers of the crab (Figure 11). During the mechanization stage, vacuum generation, electro pneumatic and artificial vision techniques were used.

For the validation of the prototype were made analyzes of possible faults and defects, and performed tests to verify interference, to then make all necessary adjustments for its full operation.

The proposal of the prototype with the principle of generation of vacuum was able to extract the meat with its less damaged muscle fiber from the crab, as well as the separation of the more humid meat (crab paste) (Figure 12). 


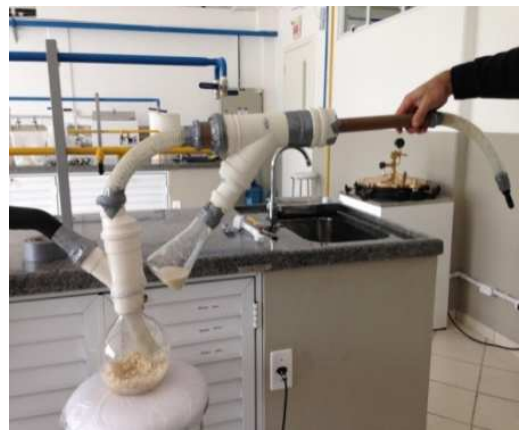

Figure 11: Equipment Prototype

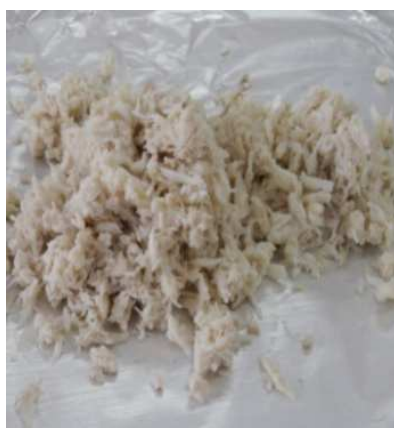

Figure 12: A) Dry meat;

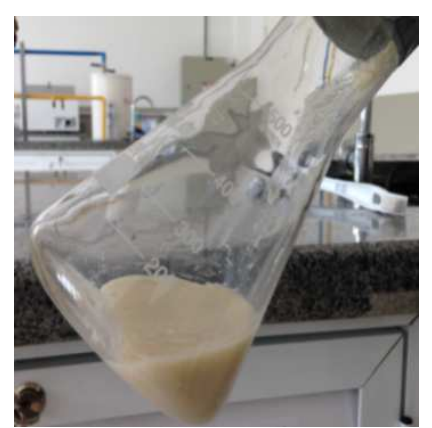

B) Wet meat.

Based on the results obtained with the prototype, the development phase of the machine itself was moved, where the dimensions and materials were adapted to meet hygiene, safety and efficiency specifications.

The constituent parts of the machine include an operating table on which is a flexible hose with a nozzle adapted for suction fitted in a stainless steel "Y" connection, which attach to hoses for separation of the dried meat of crab and paste (wet meat) that extend to the cooled reservoirs, which have a temperature and level sensor, and these reservoirs are connected to a vacuum pump with flow regulation, a vacuum gauge and a PLC.

The finished crab meat suction equipment can be observed in Figure 13, where it can be seen that for the rigid structures of the machine the stainless steel material was selected because it was inert, did not form micro cracks, had a hygienic ease and had resistance corrosion and mechanics. These characteristics together ensure the chemical and biological safety of the handled product. In the suction and conduction structures of the product, which are flexible, nontoxic food hoses were used, which do not transfer undesirable odor or taste to the product, have high temperature and abrasion resistance and are easy to clean.

The suction method used by the machine developed in this work allows the resulting products to be less exposed to contamination, since the absence of direct human contact ensures better conditions of sanity and safety to the product.

At the end of the process, two products were obtained, the wet meat and the dried and fibrous meat, which is an innovation for the market, since it presents completely different characteristics of the currently available products (Figure $14)$.

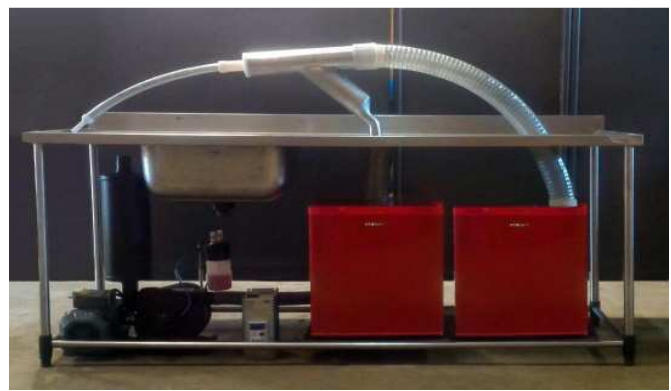

Figure 13: Equipment for extraction. of crab meat

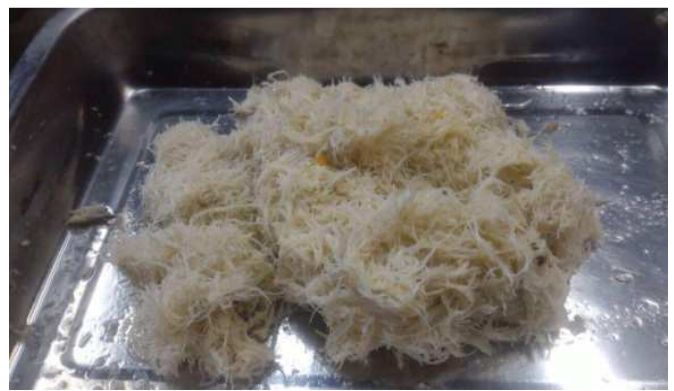

Figure 14: Dry meat obtained by the suction process in the final equipment.

\section{ACKNOWLEDGEMENTS}

The authors thank to the National Council of Scientific and Technological Development (CNPq) for the financing of the project. 


\section{CONCLUSIONS}

By means of the finishing of the machine, with this new suction technique for crab meat removal, it was possible to obtain two distinct products, the meat with different organoleptic characteristics, white color and fibrous consistency, and a crab paste. These products represent great progress in terms of innovation, appearance and sanitary quality and, consequently, bring value to the product.

The industry, including the North American - leader in the processing of crab meat, still does not have an efficient process and that guarantees high added value to the product. Based on this premise, it is understood that the market value of pure meat will encourage both fish companies and future breeding companies that can be set up, by moving the economy. The process will reduce labor accidents due to manipulation of cutting materials and will offer greater ergonomics to the manipulators, guaranteeing an efficient method both with regard to working methods and in meeting the standards of quality and food safety of the products. In addition, the labor force currently employed in the illegal and unsuitable informal dumping of the crab, which takes place around the families of fishermen, would naturally shift to the additional catch demanded by industrial scale production without the need for transfer of workers to another productive activity.

It can be said that the provision of this equipment to fishing communities can stimulate the local economy and offer better working conditions, enabling the formalization of the business. The articulations between teaching, research and community are essential to broaden the view on social needs and give visibility to the important work developed by this social body, which are often considered as "underemployment". The promotion of the practice of cooperativism, like the organization of associations and cooperatives, is capable of propitiating actions of public policies so that popular aspirations can be met. By stimulating dialogue among the various actors in the sector, it will be possible to draw up a strategy for socioeconomic developmen that is best suited to recover from subalternity, the beneficiation of the crab practiced by the riverside.

These factors have a positive impact, considering the increase in the supply of formal labor resulting from industrial scale production, as well as the expansion of the potential of labor occupation in the activity of the crab.

\section{REFERENCES}

1. Borgognoni, C.F.et al.(2006).Estabilidade de emulsões de D-limoneno em quitosana modificada.Ciência e Tecnologia de Alimentos.26(3):502-508.

2. Branco, J.O.et al.(2004).Biologia populacional de Callinectes ornatus (ordway) na Armação do Itapocoroy, Penha, Santa Catarina, Brasil.RevistaBrasileira de Zoologia, 21(1):91-96.

3. Della Fina, N.et al.(2015).Captura de Atlantoraja Cyclophora (Chondrichthyes, Rajidae) na Pesca de Camarão-Rosa no Sudeste-Sul do Brasil.RevistaCecilianaDez, 7(1):4-7.

4. Kanaga. V \& Sivasankar. P, Fishermen Constraints in Marine Fisheries at Therespuram- An Analysis, International Journal of Agricultural Science and Research (IJASR), Volume 5, Issue 2, March - April 2015, pp. 105-110

5. Josupeit, H.et al.(2004).Aquaculture - Trade, trends, standards and outlooks.Globefish.Fisheries Department, Rome, FAO.Available in: $\leq$ http://www.globefish.org/index.php?id=2061>.

6. Moura, C.M.et al.(2006).Quitina e quitosana produzidas a partir de resíduos de camarão e siri: avaliação do processo em escala piloto.Vetor.16(1): 37-45. 
7. Pahl, G.et al.(1996).Engineering Design - A Systematic Approach.Londres: Springer-Verlag.125p.

8. Pereira, M.J.et al.(2009).Population biology of Callinectesdanae and Callinectessapidus (Crustacea: Brachyura: Portunidae) in the south-western Atlantic.Journal of the Marine Biological Association of the United Kingdom, 89(7): 1341-1351.

9. Santos, C.A.M.L.(2006).A qualidade do pescado e a segurança dos alimentos.Available in: $\left\langle f t p: / / f t p . s p . g o v . b r / f t p p e s c a / q u a l i d a d e \_p e s c a d o . p d f>\right.$

10. Sidonio, L.et al.(2012).Panorama da aquicultura no Brasil: desafios e oportunidades.BNDES Setorial, 35:421-463.

11. Weber, L.I.et al.(2000).Genetic population structure of the swimming crab Callinectesdanae (Crustacea: Decapoda) in southern Brazil. Hydrobiologia, 420: 203-210. 